\title{
Quantification of genomic DNA of I 25 chickpea (cicer arietinum L.) genotypes
}

\begin{abstract}
Chickpea is one of the world's most important but less studied leguminous food crops. It is a crop of both tropical and temperate regions. With the increasing use of recombinant DNA techniques in plant research, the need of pure DNA has become a major concern. Thus, DNA extraction remains the most significant factor for largescale applications in plant breeding and germplasm characterization. We report in the current study a low-cost approach to obtain high-quality DNA from young leaves of chickpea.
\end{abstract}

Keywords: chickpea, DNA, genotypes, genomic, germplasm
Volume I Issue 5 - 2017

\author{
Himanshu Aggarwal, ${ }^{1,2}$ Jasbir Singh, ${ }^{2}$ Vikas \\ Beniwal,' Anil Kumar, ${ }^{3}$ Vinod Chhokar ${ }^{3}$ \\ 'Department of Biotechnology, Maharishi Markandeshwar \\ University, India \\ ${ }^{2}$ Departrment of Biochemistry, Kurukshetra University, India \\ ${ }^{3}$ Department of Bio and Nano Technology, Guru Jambheshwar \\ University of Science and Technology, India
}

\begin{abstract}
Correspondence: Vinod Chhokar, Department of Bio and Nano Technology, Guru Jambheshwar University of Science and Technology, India, Tel +91 999279 3333, Fax +91 I 662276240, Email vinodchhokar@yahoo.com
\end{abstract}

Received: July 09, 2017 | Published: September 05, 2017

\section{Introduction}

Chickpea (Cicer arietinum L., $2 \mathrm{n}=16$ ) is an autogamous annual cool season grain legume cultivated in arid and semi-arid areas across the world. ${ }^{1}$ It is the third most important food legume in the world after dry beans and peas. ${ }^{2}$ Chickpea was one of the first grain legumes to be domesticated in the old world. ${ }^{3}$ This primordial crop probably originated 7000 years ago in an area of present-day south-eastern Turkey and adjoining areas of Syria, and spread from there to Middle East, South Asia and North Africa, where it become an imperative crop. The plant of chickpea stands between $20 \mathrm{~cm}$ and $1 \mathrm{~m}$ tall, ${ }^{4}$ with a genome size of $740 \mathrm{Mbp},{ }^{5,6}$ slightly less than the well-characterized tomato genome $(950 \mathrm{Mbp})$. Nearly $90 \%$ of the crop is cultivated under rainfed conditions mostly on receding soil moisture. Chickpea being a rabi crop is normally sown in the month of October and harvested in March, whereas in northeastern Australia, it is sown in May/ June and harvested from October to December. ${ }^{7}$ Chickpea has high nutritive value and serves as an important cheap source of protein in developing countries diet in addition to improving land fertility. ${ }^{8}$ The main use of chickpea seeds is for human consumption, especially for strictly vegetarian people, as they are free from any anti-nutritional factors and are rich in phosphorus, calcium and digestible proteins. ${ }^{9}$ They may be consumed whole as dhal/flour, or the juvenile shoots may be eaten as a vegetable. ${ }^{4}$ It is the most economical and easily available source of carbohydrates (57-60\%), protein $(19.5 \%)$, fats $(1.4 \%)$, moisture $(4.9-15.59 \%)$ and ash $(4.8 \%)^{10}$ and it is a good source of calcium, magnesium, potassium, phosphorus, iron, zinc and manganese. ${ }^{11}$ Utilization of diverse germplasm is required to enhance the genetic variability of cultivars. The major objectives of chickpea breeding are to increase yield either by upgrading the genetic potential or by eliminating the effects of disease, pests and stress. ${ }^{12}$ Opportunity to generate favourable gene combinations can be provided by genetically diverse lines; thus, the probability of creating unique cultivars increases. ${ }^{13}$ Therefore, in the present study we extract and quantify the genomic DNA of 125 chickpea (cicer arietinum L.) genotypes.

\section{Materials and method}

Collection of germplasm and extraction of DNA: The germplasm used in the present investigation included a total of 125 genotypes which were collected during 2008-09 from Department of Plant Breeding, CCSHAU, Hisar. The leaf samples were collected in period from Jan to March, 2009. All the samples were collected in sampling bags under aseptic conditions. The leaves were stored at $-80^{\circ} \mathrm{C}$ prior to the DNA extraction. Genomic DNA was isolated from leaves of 3-4-week-old seedlings using the modified CTAB method of Thompson et al.. ${ }^{14}$ Five grams of leaf sample was taken and washed under running water and air dried so that no extra water content was left with them. The dried leaves were then ground with pestle and mortar by keeping in liquid nitrogen to attain the fine powdered form of the sample which was then transferred to $50 \mathrm{ml}$ oakridge tube. To the powdered material, $15 \mathrm{ml}$ of the extraction buffer was added and incubated at $60^{\circ} \mathrm{C}$ for about $2 \mathrm{hrs}$ in a shaking water bath (100rpm). Then equal volume of Phenol: Chloroform (1:1) was added and gently mixed for 10 minutes. The content was then centrifuged at 10,000rpm for 15 minutes at $25^{\circ} \mathrm{C}$. The supernatant was transferred to fresh tube and added equal volume of Chloroform: Isoamyl alcohol 42 (24:1) and gently mixed for 10 minutes. The content was then centrifuged at $10000 \mathrm{rpm}$ for 15 minutes at $25^{\circ} \mathrm{C}$. The supernatant was transferred to fresh tube and added $1 / 10^{\text {th }}$ volume of $3.0 \mathrm{M}$ sodium acetate $(\mathrm{pH} 5.2)$ and double volume of the ice chilled absolute ethanol. The content was then incubated at $-20^{\circ} \mathrm{C}$ for about $1 \mathrm{hr}$ followed by centrifugation at $12,000 \mathrm{rpm}$ at $4^{\circ} \mathrm{C}$ for 20 minutes. The pellet so recovered was washed twice with $70 \%$ ethanol. The pellet of DNA after air drying was then dissolved in appropriate volume of TE buffer. The quality and concentration of DNA were measured by NanoDrop spectrophotometer (ND-100) and electrophoresis using $0.8 \%$ agarose gel.

\section{Results}

The genomic DNA extracted was checked for its quality and quantity. Agarose gel electrophoresis of all the genotypes was 
performed to check the purity and integrity of the genomic DNA (Figure 1). The concentration of the genomic DNA was checked on Nano drop spectrophotometer (ND-100) and the results are reported in (Table 1). The extracted DNA is almost pure and this DNA was subjected to further treatment by RNase and Proteinase K. $\mathrm{A}_{260 / 280}$ ratio of 1.8 was obtained in all the 125 samples after the treatment.

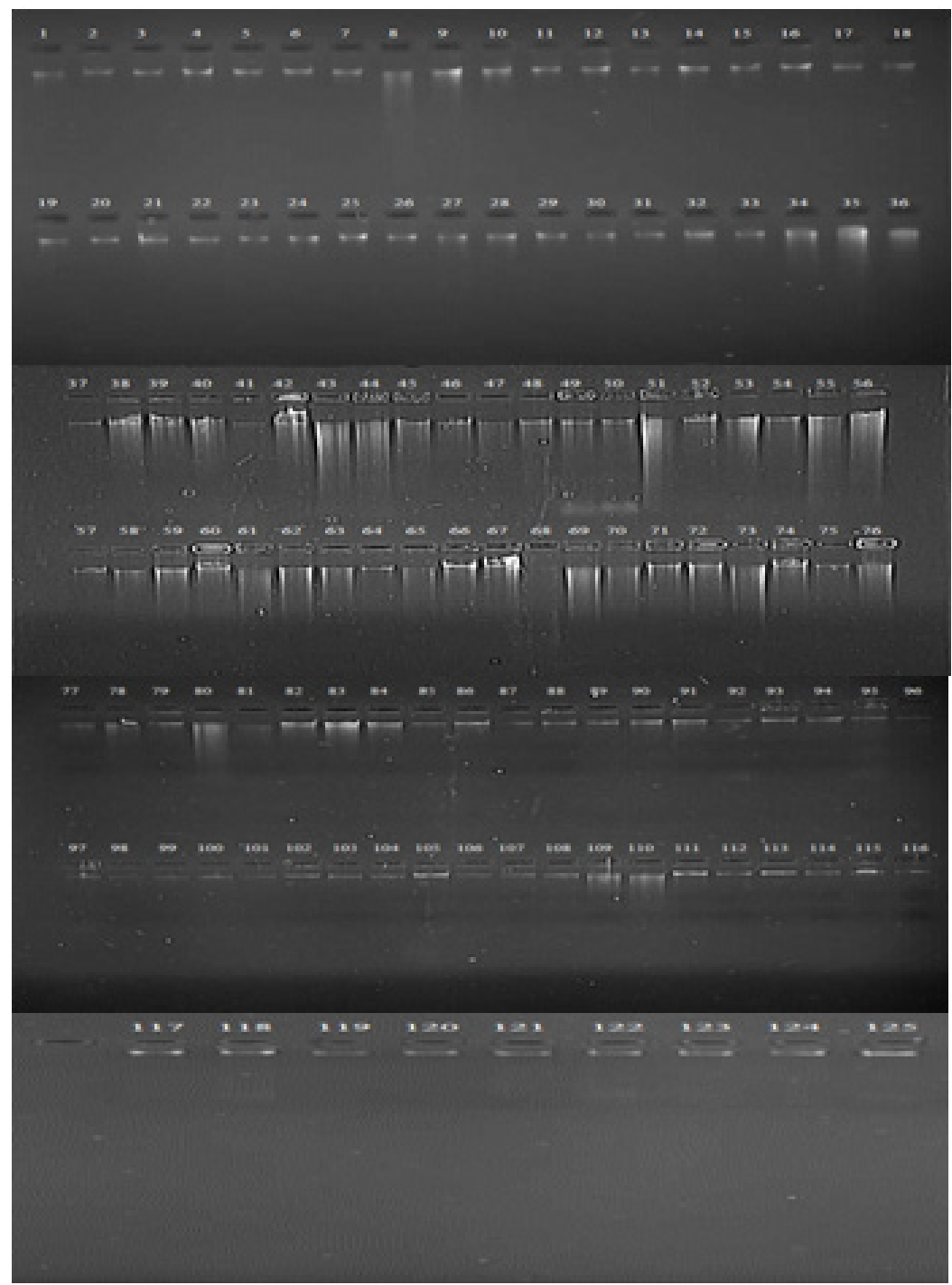

Figure I Genomic DNA of Cicer arietinum genotypes I-I25 used in the present study without RNase and Proteinase K treatment.

Table I Concentration of DNA(ng/ $\mu \mathrm{l})$ of I25 chickpea genotypes per $5 \mathrm{~g}$ dry weight of leaves and their A260/280 ratio without RNase and Proteinase $\mathrm{K}$ treatment

\begin{tabular}{llllll}
\hline Genotype & A260/280 & Concentration & Genotype & A260/280 & Concentration \\
\hline ICCV 4958 & 2.01 & 568.1 & RSG 973 & 1.75 & 3827.6 \\
Katila & 2.1 & 1068.3 & RSG 888 & 1.72 & 594.6 \\
PDG 84-I6 & 1.46 & 328.1 & HC-I & 1.84 & 4225.5 \\
BG 276 & 1.93 & 3252.9 & Pusa 256 & 1.03 & 3639.2 \\
Tyson & 1.66 & 498.8 & Pusa 362 & 1.1 & 3677.6 \\
H-208 & 1.6 & 5012.5 & Vishal & 1.31 & 5111.8 \\
HC-3 & 1.99 & 2371.3 & H04-45 & 1.5 & 4229.6 \\
E I00Ym & 2 & 1181.3 & HC-5 & 1.1 & 4362.2 \\
GNG 663 & 1.97 & 735.7 & H03-56 & 1.8 & 3682.9 \\
\hline
\end{tabular}


Table Continued..

\begin{tabular}{|c|c|c|c|c|c|}
\hline Genotype & A260/280 & Concentration & Genotype & A260/280 & Concentration \\
\hline C-235 & 1.84 & 393.9 & Gaurav & 2.03 & 7842.6 \\
\hline DCP 92-3 & 1.99 & 1485.9 & ICC 4958 & 1.99 & 5382.9 \\
\hline Radhey & 1.8 & 4233.6 & Amethyst & 2.02 & 4474.4 \\
\hline RSG 963 & 1.95 & 238.8 & WR-3I5 & 2.01 & 5029.4 \\
\hline Pusa 26I & 1.93 & 2875.6 & ICCV92944 & 2.07 & 1458.5 \\
\hline Annegiri & 1.86 & 564.9 & ICCV96030 & 1.5 & 5075.9 \\
\hline RSG 931 & 1.95 & 2238 & L 55I & 1.96 & 944.8 \\
\hline GNG I46 & 1.84 & 4228.3 & Pusa 1053 & 1.93 & 877.3 \\
\hline BGM 408 & 1.89 & 3120.1 & L 550(k) & 1.94 & 1512.6 \\
\hline Pusa 267 & 1.8 & 1945.6 & ICCV-2 & 1.92 & 715.6 \\
\hline Vijay & 1.88 & 3715.8 & JG 74 & 1.5 & 4959.6 \\
\hline HK 94-I34 & 1.98 & 742.9 & JKG-I(k) & 1.26 & 5089.7 \\
\hline GNG 469 & 1.97 & 2921.3 & RSGK-6(k) & 2.15 & 1818.5 \\
\hline JG 315 & 1.96 & 601.7 & $J G-64$ & 1.3 & 4180.8 \\
\hline BGD 72 & 1.92 & 1681.4 & ICCV-IO & 1.92 & 5449.2 \\
\hline PBG-I & 1.33 & 4679.8 & BushyMutant & 1.95 & 6311.1 \\
\hline Avrodhi & 1.93 & 1460.4 & Hima & 1.8 & 4771.3 \\
\hline CSG 8962 & 1.27 & 5203.7 & BG 396 & 2.08 & 1082.1 \\
\hline Pusa 372 & 1.68 & 4147 & BG 1006 & 2.12 & 1001.6 \\
\hline HK 98-I55 & 1.8 & 3663.4 & IPC 92-39 & 2.08 & 2141.9 \\
\hline IPC 98-I2 & 2.12 & 2260.4 & GCP IOI & 1.5 & 5133.8 \\
\hline ICCVI4880 & 2.1 & 2955.2 & BGM 413 & 2 & 808.4 \\
\hline IPC 99-18 & 1.97 & 2613.1 & $\operatorname{Virat}(k)$ & 1.21 & 4727.9 \\
\hline IPC2000-33 & 1.8 & 4550.7 & PBG-5 & 1.6 & 4516.8 \\
\hline IPC 200I-2 & 1.35 & 5127.5 & PDG 4 & 1.62 & 4394 \\
\hline IPC 95-I & 1.95 & 2579.7 & RSG 44 & 1.38 & 4655.6 \\
\hline PG 96006 & 1.96 & 2855.1 & Pusa 212 & 1.3 & 5180.3 \\
\hline IPC 97-67 & 1.98 & 890.1 & GL 769 & 1.8 & 4552.9 \\
\hline IPC 94-94 & 1.98 & 1781.6 & Vaibhava & 1.8 & 4493 \\
\hline IPC2000-4I & 1.98 & 260.3 & KPG 59 & 1.41 & 5107.4 \\
\hline IPC2000-45 & 1.85 & 1075.3 & ICCV 37 & 1.74 & 4679.7 \\
\hline RSG 807 & 1.97 & 818.2 & Pusa 391 & 1.93 & 2933.7 \\
\hline Pusa 209 & 1.71 & 628.5 & SAKI95I6 & 1.8 & 3709.3 \\
\hline CSJD-844 & 1.97 & 1782.5 & GCP 105 & 1.93 & 2921.3 \\
\hline GG-2 & 1.94 & 3173.5 & RAU 52 & 1.71 & 3893.3 \\
\hline RS- 10 & 1.95 & 1570.7 & Pusa 240 & 1.18 & 4317.4 \\
\hline Pusa 244 & 1.85 & 3341.4 & Sadabahar & 1.64 & 4012.5 \\
\hline GPF-2 & 1.88 & 2152.2 & RSG-II & 1.7 & 3824.1 \\
\hline JGG-I & 1.95 & 1614.9 & Pusa 329 & 2.13 & 1504.2 \\
\hline PG 12 & 1.75 & 4420.8 & Dohadyellow & 1.07 & 5176.3 \\
\hline RSG-2 & 1.94 & 1191.4 & Pusa 1003 & 1.83 & 4169.2 \\
\hline Chaffa & 2.08 & 387.5 & JG 130 & 1.89 & 3767.7 \\
\hline
\end{tabular}

Citation: Aggarwal H, Singh J, Beniwal V, et al. Quantification of genomic DNA of I25 chickpea (cicer arietinum L.) genotypes. MOJ Biol Med. 20I7; I (5): I43-I46. DOI: 10.15406/mojbm.2017.01.0003। 
Table Continued..

\begin{tabular}{llllll}
\hline Genotype & A260/280 & Concentration & Genotype & A260/280 & Concentration \\
\hline PDG-3 & 2.04 & 445.8 & B I08 & 1.3 & 5087.9 \\
GNG I292 & 1.75 & 2826.6 & BGD 75 & 1.5 I & 3600.3 \\
JG II & 1.92 & 3074.6 & C 214 & 1.31 & 4309.6 \\
KWR I08 & I.46 & 5027.7 & C I5 & 1.04 & 4385.6 \\
JG 218 & 1.93 & 2085.6 & C 20 & 1.66 & 4098.6 \\
Phule G-5 & I.91 & 1014.7 & C I6 & 1.76 & 3732.2 \\
Pant GII4 & 1.94 & 3483 & M I & 1.2 & 3211.6 \\
Pusa 3I2 & 1.9 & 3739.8 & M 2 & 1.75 & 2062.1 \\
K 850 & 1.91 & 491.7 & H04-57 & 1.04 & 2174.3 \\
H04-44 & 1.08 & 5240.9 & Digvijay & 2 & 6988.6 \\
H04-87 & 1.96 & 2416 & PantG I86 & 1.9 & 2270 \\
H04-II & 1.4 & 4295.1 & & & \\
\hline
\end{tabular}

\section{Conclusion}

The process of germplasm selection is usually based on the evaluation of agronomical traits, breeding value and phytopathological characteristics, but pure and integrated DNA is most pre-requisite condition for any breeding programme. The current protocol was very economical as all the chemicals used in the present study were of analytical grade (sigma and S.D.Fine-Chem) while, solutions were prepared in the laboratory, whenever required.

\section{Acknowledgements}

The authors thank Dr. VirenderLathar and Dr. Neeraj Kumar, Department of Plant Breeding, CCSHAU, Hisar (Haryana) India, for providing plant samples. This work was supported financially by HSCST (Haryana State Council for Science and Technology), Panchkula (Haryana) India in the form of Major Research Project.

\section{Conflict of interests}

The authors declared there is no conflict of interest.

\section{References}

1. Iruela M, Castro P, Rubio J, et al. Validation of a QTL for resistance to ascochyta blight linked to resistance to fusirium wilt race 5 in chickpea (Cicer arietinum L.). Europian Journal of Plant Pathology. 2007;119:29-37.

2. FAOSTAT. Food and Agriculture Organization of the United Nations. Europe: 2004.

3. Van der Maesen LJG. Origin, history and taxonomy of chickpea. In: Saxena MC, et al. Editors. The Chickpea, CAB International, UK: 1987. p. 11-34.

4. Muehlbauer FJ, Tullu A, Cicer arietinum L. New CROP Fact SHEET. USA: Washington State University; 1997. p. 1-6.
5. Arumuganathan K, Earle ED. Nuclear DNA content of some important plant species. Plant Molecular Biology Reporter. 1991;9(3):208-218.

6. Coram TE, Mantri N, Ford R, et al. Functional genomics in chickpea: an emerging frontier for molecular-assisted breeding. Functional Plant Biology. 2007;34:861-873.

7. Knights EJ. Facication in chickpea: genetic and evolution. Euphytica.1993;69:163-166.

8. Saeed A, Hovsepyan H, Darvishzadeh R, et al. Genetic diversity of Iranian accessions, improved lines of chickpea (cicer arietinum L.) and their wild relatives by using simple sequence repeats. Plant Molecular Biology Reporter. 2011;29(4):848-858.

9. Rana S, Singh P, Sharma KK, et al. Invitro regeneration and genetic transformation of chickpea. Applied genetics of leguminosae biotechnology, Dordrecht, Netherlands: 2003. p. 69-87.

10. Huisman J, Van der Poel AFB. Aspects of the nutritional quality and use of cool season food legumes in animal feed. In: Muehlbauer FJ, et al. editor. Expanding the Production and Use of Cool Season Food Legumes. Dordrecht, the Netherlands: Kluwer Academic Publishers; 1994. p. 53-76.

11. Ibrikci H, Knewtson S, Grusak MA. Chickpea leaves as a vegetable green for humans: Evaluation of mineral composition. Journal of the Science of Food and Agriculture. 2003;83(9):945-950.

12. Aggarwal H, Singh J, Khaket TP, et al. Genetic diversity in chickpea using various molecular markers: first step towards molecular breeding. International Journal of Advanced Research. 2013;1(4):393-398.

13. Aggarwal H, Rao A, Kumar A, et al. Assessment of genetic diversity among 125 cultivars of chickpea (Cicer arietinum L.) of Indian origin using ISSR markers. Turkish Journal of Botany. 2015;39(2):218-226.

14. Murray MG, Thompson WF. Rapid isolation of high molecular weight plant DNA. Nucleic Acid Research. 1980;8(19):4321-4325. 